\title{
Intracategorial Varieties of Contempt in a Heterogeneous Sample*
}

\section{Variedades intracategoriales del desprecio en una muestra heterogénea}

Recibido: abril 14 de 2012 | Revisado: septiembre 3 de 2012 | Aceptado: septiembre 26 de 2012

\author{
ANA R. DELGADO ** \\ Margarita G. MÁrQUeZ **** \\ Universidad de Salamanca, España
}

doi:10.11144/Javeriana.UPSY12-2.ivch

Para citar este artículo: Delgado, A. R. \& Márquez, M. G. (2013). Intracategorial varieties of contempt in a heterogeneous sample. Universitas Psychologica, $12(2), 357-362$.

* This research was supported by research grant MICINN PSI2009-09490. We wish to thank Carlota Calvo and Marta Montero for acting as blind coders, and the University of Salamanca for lending us a space for carrying out the interviews in the historical building.

*** Universidad de Salamanca, Spain. Professor at the Universidad de Salamanca in the Department of Basic Psychology, Psychobiology and Methodology. E-mail: adelgado@usal.es

${ }^{* * * *}$ Universidad de Salamanca, Spain. FPU Scholar in the Department of Basic Psychology, Psychobiology and Methodology. E-mail: mgmarquez@usal.es

\section{A B S T R A C T}

Consistent with current emotion theory, we should note that contempt is not a homogeneous category but rather shows intracategorial variability. Previous research on Spanish samples shows a communicative structure in which contempt is felt towards intimate, social or abstract receivers, for reciprocal, altruistic or prejudiced reasons. Our objective was to test, on a large and heterogeneous sample, the previously found structure and variations of the experience of contempt as well as its spontaneous facial expression. Testing the association of contempt varieties with certain subject attributes was a secondary goal. Results from 130 participants from the Spanish general population corroborated the previously found structure and varieties, as well as the associations between contempt receiver and attribution. No relation was found with sex, age or emotion recognition ability. As to spontaneous facial expression, disgust was more often expressed by those who narrated their personal episodes of contempt for reciprocal reasons, and was less often expressed by the people who described prejudiced scenarios. This result indicates that the conventionally considered facial expression of contempt is not the only one, as already stated by Darwin, and should not be considered as such by experimental and psychometric procedures. Key words authors

Construct Validity, Contempt, Disgust, Emotion Recognition.

Key words plus

Intracategorial Variability, Moral Psychology, Quantitative Research.

\section{RESUMEN}

De forma consistente con las teorías actuales de la emoción, el desprecio no es una categoría homogénea, sino que presenta variedad intracategorial. La investigación previa en muestras españolas muestra una estructura comunicativa en la que el desprecio se experimenta hacia receptores íntimos, sociales o abstractos por razones recíprocas, altruistas o prejuiciosas. Nuestro objetivo fue poner a prueba, en una muestra grande y heterogénea, la estructura previamente encontrada para la experiencia de desprecio, así como sus variedades y expresión facial espontánea. Un objetivo secundario fue la puesta a prueba de la asociación de las variedades del desprecio con atributos de sujeto. Los resultados de 130 entrevistas procedentes de población general española corroboraron la estructura y variedades previamente halladas, así como la asociación entre el receptor del desprecio y la atribución causal. La relación con el sexo, la edad y la aptitud de reconocimiento emocional no resultó significativa. Con respecto a la expresión facial, la de asco apareció con mayor frecuencia en quienes narraron episodios de desprecio por razones de reciprocidad y con menor frecuencia en quienes describieron escenarios prejuiciosos. Este resultado indica que la expresión convencionalmente considerada como de desprecio no es la única, como ya 
estableció Darwin, por lo que no debería considerarse como tal en los procedimientos experimentales y psicométricos. Palabras clave autores

Validez de constructo, asco, desprecio, reconomiento emocional. Palabras clave adicionales

Variabilidad intracategorial, Psicología moral, investigación cuantitativa.

Contempt is one of the most culturally variable emotions (Elfenbein \& Ambady, 2002; Elfenbein, Beaupré, Lévesque \& Hess, 2007). It is an especially salient emotion in Spain (Delgado, 2009a) although, consistent with current emotion theory, we should note that it is not a homogeneous category but rather shows intracategorial variability (Barrett, 2009).

Previous research on Spanish samples shows a communicative structure in which contempt is typically felt for someone (a) who has done something wrong to the participant, (b) who has done something wrong to a third party, or (c) whose characteristics are disliked (Delgado, 2009b; Delgado \& Márquez, (2013). These varieties, reflecting the Why, will be called reciprocal, altruistic and prejudiced, respectively. The usual association between contempt and prejudice (e.g., Fiske, Cuddy, Glick $\& \mathrm{Xu}, 2002)$ also appears in these data: contempt episodes reflecting prejudice are always modal, but altruistic and reciprocal motives are also reported. As to the objects or receivers of contempt, reflecting the Whom, they were also bottom-up classified in threes: intimate, social and abstract. Phenomenological analysis of self-reported personal experiences has shown some reciprocal episodes in which the object of contempt is a loved person or a friend, i.e., someone close in the psychological space, but abstract receivers are still modal (Delgado, 2009b).

It has also been found that the use of the term "contempt" (in Spanish 'desprecio') relates to at least one of the following elements: an avoiding attitude, a negative experience or a feeling of superiority, which is consistent with expert opinion, although some kind of rejection is mentioned more than expected for a "cold" emotion. Delgado (2009b) found that avoiding was the most mentioned element, followed by negativity; although contempt is usually described as an emotion associated with social hierarchy, superiority was in fact the least frequent of the three.

In the Moral Psychology field, where emotions are increasingly being taken into account, contempt, anger and disgust -the CAD triad- are regarded as affective reactions to the violation of different community duties (Haidt, 2007; Rozin, Lowery, Imada \& Haidt, 1999). Evolutionary theories have described moral offences as sociocognitive extensions of the disgust evaluation system (Rozin, Haidt \& Fincher, 2009). However, the fact that some moral offence triggers the same facial motor activity as core disgust elicitors (Chapman, Kim, Susskind \& Anderson, 2009) is not a robust corroboration of the disgust exaptation hypothesis (Rozin et al., 2009). Alternative views such as Darwin's (1872) -that a slight turning up of the nose is one of the common contempt expressions- are compatible with these results. Corroborating Darwin's view is the fact that spontaneous expressions that would be conventionally coded as disgust faces have been registered while people narrate episodes of contempt (Delgado, 2009b).

As to altruism, even though reciprocity has a star role in the current moral psychology (Cosmides \& Tooby, 2005), it is still considered that truly moral choices imply doing something for a third party when egoistic motivation would lead us to act in a different way. Emotions seem to be important proximate factors behind altruistic punishment (Fehr \& Gächter, 2002; Moll, De Oliveira-Souza \& Zahn, 2008). In this sense, the moral role of anger has already been described (Averill, 1982).

Currently, the main methodological critique against moral psychology has to do with the lack of representativeness that makes generalization problematic (Baumard \& Sperber, 2010). Volunteers solving artificial moral dilemmas in laboratories (Bloom, 2010) do not seem a good recipe for achieving construct validity. Thus our first objective was to corroborate (or else refute) the previously found structure and variations of the experience of contempt with a heterogeneous sample, as well as the associated spontaneous facial expression. Testing the association of contempt varieties with subject 
attributes (age, gender and emotion recognition abilities) was a secondary goal. In this way, we control by inclusion some variables that could serve as plausible explanations for the intracategorial variability of contempt.

\section{Method}

\section{Participants}

Some 130 participants from the Spanish general population were selected in the downtown of a monumental city and interviewed in a quiet room in a Historical building. The sample was composed of 63 females and 67 males. They belonged to all age groups $(M=42.6 ; S D=16.11$; range $=18-75)$. Regarding their geographic procedence, 15 out of 17 were from Spanish autonomous communities, and two from autonomous cities (Ceuta and Melilla).

\section{Procedure}

The participants were interviewed about (a) their general idea of contempt, (b) a typical contempt episode, and (c) a personal episode. Later on, they completed tasks of emotional recognition (caucasic faces from JACBART) and expression. Interviews were registered with a MacBook portable computer with iSight webcam and saved in iMovie. The 130 participants provided informed consent.

The three elements of the general idea of contempt (avoiding, negativity and superiority) were coded as present or absent and then added up: two subjects that obtained a zero score were eliminated from the sample, given their inability to define contempt in even the most basic way. Both the typical and personal episodes were categorized by means of two concurrent category systems each, describing the receivers (intimate, social and abstract) and reasons (reciprocal, altruistic and prejudiced) of contempt. No other category showed prevalence and we therefore considered that saturation was reached.

Two "blind" observers, carefully selected to warrant a very high level of reading comprehension, independently read and coded the transcribed interviews. They met afterwards in order to comment their disagreements and solve them when possible. Kappa values were calculated to estimate the interobserver consistency that ranged from 0.73 (typical episode object) to 0.95 (personal episode object).

As to the spontaneous contempt, anger and disgust expressions, they were coded by the second author, who had been instructed to detect micro expressions and subtle expressions with training software based on Ekman (2003) until reaching the maximum accuracy level. The expressions were registered from mute videos of the interviews and then coded as present or absent. Kappa values for intraobserver consistency were 0.54 (contempt), 0.83 (disgust) and 0.76 (anger). Data from the second occasion (one-month separated from the first) will be reported here, although it must be noted that the results calculated with the first occasion's data do give rise to the same conclusions.

\section{Results}

The 128 participants mentioned at least one of the three elements previously found in definitions of contempt. Negativity was the most salient of the three $(f=114)$, followed by some sort of avoiding $(f=76)$, and superiority $(f=41)$. As already mentioned, data from the two participants who failed to mention any of these elements were not considered further.

One hundred and twenty subjects told typical episodes that could be coded with the attribution and receiver categories. Concerning attributions, the expected order, from a previous small sample study, was (1) prejudiced, (2) altruistic, (3) reciprocal, but results (see Table 1) show that prejudiced motives are followed in frequency by reciprocal and then altruistic ones. As predicted from previous research, the abstract receivers were followed, in frequency, by social and intimate ones. The association between these nominal scale variables was statistically significant and medium-sized, $\chi^{2}(4)=13.15$, Cramer's $V=0.23, p=0.011$.

Table 1 cells show corrected standardized residuals indicating that contempt is, more than 
TABLE 1

Typical: Attribution by Receiver. Frequency (Corrected Standardized Residual)

\begin{tabular}{llcccc}
\hline & & Intimate & Social & Abstract & Total \\
\hline Attribution & Reciprocal & $3(3.2)$ & $3(1.4)$ & $14(-3.0)$ & 20 \\
& Altruistic & $0(-.6)$ & $0(-.9)$ & $9(1.1)$ & 9 \\
& Prejudice & $1(-2.4)$ & $6(-.7)$ & $84(2.0)$ & 91 \\
\hline Total & & 4 & 9 & 107 & 120 \\
\hline
\end{tabular}

Source: own work

expected under null hypothesis, thought to be felt for close others who have done wrong to the person feeling the emotion; or for people in the abstract (including institutions) due to their intrinsic attributes, i.e., prejudice. As expected, the latter was the modal typical episode.

Association tests between attribution and spontaneous expressions of contempt $\left(\chi^{2}(2)=1.30\right.$, Cramer's $\left.V=0.10, p=0.523\right)$, disgust $\left(\chi^{2}(2)=0.94\right.$, Cramer's $\left.V=0.09, p=0.624\right)$, and anger $\left(\chi^{2}(2) 0=1.85\right.$, Cramer's $V=0.12$, $p=0.396)$ were no significant and small-sized. Neither was the association of attribution with gender significant, $\chi^{2}(2)=3.54$, Cramer's $V=0.17$, $p=0.17$. One-way ANOVAs were carried out to test for significant differences associated to attribution in age $(F(2,117)=0.217, p=0.805)$ and emotion recognition ability $(F(2,117)=1.22$, $p=0.299)$. No significant differences were found.

As to personal episodes, 90 participants reported episodes that could be coded with the attribution categories. Of these, 89 could be coded with the receiver categories as well. (Among the remaining cases, there were people who insisted in that they had never felt contempt for another person or who told stories in which they were the victims of contempt, despite being politely reminded of the real question by the interviewer). The expected order was: reciprocal, prejudiced and altruistic. However, as with typical episodes, prejudiced motives were followed in frequency by reciprocal and altruistic ones (see Table 2). As to receivers, the expected order was abstract, social, intimate. The results show abstract receivers followed by intimate and social ones (that show very similar frequencies). The association between attribution and receiver variables was statistically significant and largesized, $\chi^{2}(4)=28.97$, Cramer's $V=0.40, p<0.001$.

Table 2 cells show corrected standardized residuals indicating that contempt is, more than expected under the null hypothesis, felt towards intimate and social others who have done us wrong, or for abstract objects due to either altruistic or prejudiced reasons.

Association tests between attribution and spontaneous expressions of contempt $\left(\chi^{2}(2)=0.98\right.$, Cramer's $V=0.10, p=0.613)$ and anger $\left(\chi^{2}(2)=1.65\right.$, Cramer's $V=0.14, p=0.437$ ) were no significant and small-sized. However, we find a significant association of attributions with spontaneous expressions of disgust $\left(\chi^{2}(2)=7.89\right.$, Cramer's $V=0.30$, $p=0.019$ ).

Table 3 shows corrected standardized residuals indicating that disgust was more often spontane-

TABLE 2

Personal: Attribution by Receiver Frequency (Corrected Standardized Residual)

\begin{tabular}{llcccc}
\hline & & Intimate & Social & Abstract & Total \\
\hline Attribution & Reciprocal & $11(3.5)$ & $10(3.2)$ & $12(-5.2)$ & 33 \\
& Altruistic & $0(-2.1)$ & $0(-2.0)$ & $18(3.1)$ & 18 \\
& Prejudice & $3(-1.8)$ & $3(-1.5)$ & $32(2.6)$ & 38 \\
\hline Total & & 14 & 13 & 62 & 89 \\
\hline
\end{tabular}

Source: own work 
TABLE 3

Personal: Attribution by Spontaneous Expression of Disgust

\begin{tabular}{llccc}
\hline & & Absent & Present & Total \\
\hline Attribution & Reciprocal & $17(-2.7)$ & $16(2.7)$ & 33 \\
& Altruistic & $13(.3)$ & $5(-.3)$ & 18 \\
& Prejudice & $32(2.4)$ & $7(-2.4)$ & 39 \\
\hline Total & & 62 & 28 & 90 \\
\hline
\end{tabular}

Source: own work

ously expressed by those who narrated their personal episodes of contempt for reciprocal reasons, and less often expressed by people describing prejudiced scenarios.

The association of attribution with gender was nonsignificant, $\chi^{2}(2)=1.76$, Cramer's $V=0.14$, $p=0.415$. One-way ANOVAs showed no differences associated with attribution in either emotion recognition ability $(F(2,87)=1.86, p=0.162)$ or age $(F(2,87)=3.98, p=0.022$; Bonferroni corrected post-hoc analysis showed no significant differences).

\section{Discussion}

This study corroborates, in a heterogeneous sample, the previously found structure and variations -reciprocal, altruistic and prejudiced- of the experience of contempt. The moral role of contempt, a prevalent emotion in Spain (Delgado, 2009a), has not been limited to reciprocal scenarios, but altruistic ones have also appeared, especially when subjects reported personal experiences. However, contempt as prejudice is still the modal representation.

Although the association of the spontaneous facial expression conventionally coded as disgust with contempt episodes is not new (e.g., Darwin, 1872; Delgado 2009b), the fact that the conventionally called disgust face was shown more often in people who narrated personal episodes of contempt for reciprocal reasons, and less often in those describing prejudiced scenarios has not been reported before, as far as we know. This result indicates that intracategorial variability is not only detected in self-reports and written documents, but also in facial expressions. It is also consistent with recent experimental results by Moretti and di Pellegrino (2010) in an economic decision context.

It could well be that what experimental psychologists are now calling socio-moral disgust was just a metaphorical way of referring to contempt. If this is so, attempts to find a common neural network could not be the best methodological strategy. Moretti and di Pellegrino (2010) have suggested that disgust is not a unitary concept, and we have found evidence for the intracategorial variability of contempt. As long as emotion varieties are not included in experimental designs, it will never be clear whether socio-moral disgust is a variety of contempt or vice versa.

From a behavioral science perspective, it would be useful to carry out some research by means of structured interviews in order to investigate what action tendencies allow to differentiate among the CAD emotions. Although subjects seldom mention action tendencies in open interviews, they are needed to behaviorally characterize the emotion varieties.

No association of contempt varieties with commonly studied subject attributes (age, gender and emotion recognition abilities) were found, and thus they can be refuted as plausible explanations for the varieties of contempt. Our results, calculated using a large and heterogeneous sample, do not show different contempt representations by gender, age or emotional intelligence (of which emotion recognition is a basic proxy). Were these results replicated in future studies, then some grounded theorization could be developed in order to account for them, allowing the deduction and testing of hypothesis. 
Finally, it is seldom mentioned that one of the main reasons for the artificiality of Moral Psychology research (Bloom, 2010) is the lack of construct validity of manipulated variables. We believe that a good starting point for solving this problem is to take into account the results from bottom-up studies showing ecological evidence of intracategorial emotion variability.

\section{References}

Averill, J. R. (1982). Anger and aggression: An essay on emotion. New York: Springer-Verlag.

Barrett, L. F. (2009). Variety is the spice of life: A psychologist constructionist approach to understanding variability in emotion. Cognition $\mathcal{E}$ Emotion, 23(7), 1284-1306.

Baumard, N. \& Sperber, D. (2010). Weird people, yes, but also weird experiments. Behavioral and Brain Sciences, 33(2-3), 84-85.

Bloom, P. (2010). How do morals change? Nature, 464, 490-490.

Chapman, H. A., Kim, D. A., Susskind, J. M. \& Anderson, A. K. (2009). In bad taste: Evidence for the oral origins of moral disgust. Science, 323(5918), 1222-1226.

Cosmides, L. \& Tooby, J. (2005). Neurocognitive adaptations designed for social exchange. In D. M. Buss (Ed.), Evolutionary psychology handbook (pp. 548-627). New York: Wiley.

Darwin, Ch. (1872). The expression of the emotions in man and animals. London: John Murray.

Delgado, A. R. (2009a). Spanish basic emotion words are consistently ordered. Quality \& Quantity, 43(3), 509-517.

Delgado, A. R. (2009b). Social robots, moral emotions. Proceedings of the 11th International Conference on Enterprise Information Systems, Vol. AIDSS, 263-270.
Delgado, A. R. \& Marquez, M. G. (2013). Social robots, cross-cultural differences. Manuscript submitted for publication.

Ekman, P. (2003). Emotions revealed: Recognizing faces and feelings to improve communication and emotional life. New York: Times Books.

Elfenbein, H. A. \& Ambady, N. (2002). On the universality and cultural specificity of emotion recognition: A meta-analysis. Psychological Bulletin, 128(2), 203-235.

Elfenbein, H. A., Beaupré, M. G., Lévesque, M. \& Hess, U. (2007). Toward a dialect theory: Cultural differences in the expression and recognition of posed facial expressions. Emotion, 7(1), 131-146.

Fehr, E. \& Gächter, S. (2002). Altruistic punishment in humans. Nature, 415, 137-140.

Fiske, S. T., Cuddy, A. C., Glick, P. \& Xu, J. (2002). A model of (often mixed) stereotype content: Competence and warmth respectively follow from perceived status and competition. Journal of Personality and Social Psychology, 82(6), 878-902.

Haidt, J. (2007). The new synthesis in moral psychology. Science, 316(5827), 998-1002.

Moll, J., De Oliveira-Souza, R. \& Zahn, R. (2008). The neural basis of moral cognition. Sentiments, concepts, and values. Annals of the New York Academy of Sciences, 1124, 161-180.

Moretti, L. \& di Pellegrino, G. (2010). Disgust selectively modulates reciprocal fairness in economic interactions. Emotion, 10(2), 169-180.

Rozin, P., Haidt, J. \& Fincher, K. (2009). From oral to moral. Science, 323(5918), 1179-1180.

Rozin, P., Lowery, L., Imada, S. \& Haidt, J. (1999). The CAD triad hypothesis: A mapping between three moral emotions (contempt, anger, disgust) and three moral codes (community, autonomy, divinity). Journal of Personality and Social Psychology, 76(4), 574-586. 